\title{
Smíšený výzkum: Jedná se o nové a závažné téma? ${ }^{1}$ \\ Mixed methods design: New and crucial topic? \\ Kateřina Vlčková
}

\begin{abstract}
Abstrakt: Smíšený výzkum je jedním z nových a závažných témat metodologie sociálních věd. Vzhledem k typickým výzkumným otázkám se jedná o zásadní design výzkumu pedagogických disciplín, zejména pedagogické evaluace. Stručně naznačujeme historii smíšeného výzkumu, jeho současné pojetí, kritéria jeho závažnosti a rozšíření, vybrané a zajímavé oblasti jeho př́nosu pro pedagogický výzkum a otázky odpovídající české terminologie.
\end{abstract}

Klíčová slova: smíšený výzkum, smíšený design výzkumu, kvalitativní výzkum, kvantitativní výzkum, metodologie, pedagogický výzkum, design výzkumu.

\begin{abstract}
Mixed methods design (MMD) is one of the new approaches and important topics in current research methodology in social sciences. Regarding the typical research questions it is a crucial research design in educational sciences; evaluation above all. The paper shortly summarizes the history and current understanding of MMD, criteria for its importance and expansion, selected interesting areas of its benefits for educational research, and questions of relevant Czech MMD terminology.
\end{abstract}

Keywords: mixed method design, qualitative research, quantitative research, methodology, educational research, research design.

\section{1 Úvod}

Př́spěvek je shrnutím koreferátu k plenárním referátům předneseným na konferenci České asociace pedagogického výzkumu v Brně dne 5. 9. 2011. Rozvíjí téma konference Smíšený design v pedagogickém výzkumu a navazuje na referáty prof. J. Mareše na téma edukace založené na důkazech a prostor pro smíšenou metodologii a prof. M. M. Bergmana o smíšeném designu výzkumu, jeho prínosech a problémech. V kontextu tématu konference si můžeme položit otázku, zda je smíšený výzkum novým a závažným tématem.

Podobnou otázku si můžeme klást u edukace a vzdělávací politiky založené na důkazech. Zde podle našeho názoru navazujeme na tradici tématu vztahu teorie a praxe v České republice. $\mathrm{Na}$ druhou stranu se však o evidence based policy a evidence based practice v moderním pojetí začalo diskutovat $\mathrm{v}$ medicíně až od začátku devadesátých let 20 . století a ve vzdělávání po roce 2000 (Shavelson \& Towne, 2002). V současnosti se dané téma vyvíjí směrem $\mathrm{k}$ evidence informed practise a evidence informed policy - vzhledem k problematickým epistemologickým východiskům předešlého konceptu (Prenzel, 2011).

\footnotetext{
${ }^{1}$ Tato studie vznikla za podpory MŠMT ČR v rámci projektu „Centrum základního výzkumu školního vzděláváni“"s registračním číslem LC06046.
} 


\section{Historie smíšeného výzkumu}

Podobně smíšený výzkum není ve svých základech zcela novinkou. Jako gnoseologické téma kombinace metod bylo známé mimo jiné ve starověké řecké filozofii. Jednalo se o diskusi o jedné, univerzální pravdě versus více pravd, resp. relativní pravdě či určité střední cestě (Sokrates, sofisté, Platón, Aristoteles aj.). V západní filozofii a vědě je tato debata živá v jistém slova smyslu dodnes.

Co se týče smíšeného výzkumu, od roku 1900 do roku 1950 byla kombinace metod běžná a termín smíšený výzkum nebyl používán. Do sedmdesátých let poté převládal v sociálních vědách vzor př́rodních věd a diskutovalo se o efektu použití metod. V důsledku čehož se doporučovalo měřit konvergentně s více metodami (Campbell \& Fiske, 1959). Do roku 1985 sílil konstruktivismus a kvalitativní výzkum jako obrana proti hlavnímu kvantitativnímu proudu. Denzin (1978) rozpracovával známý koncept triangulace aplikovaný u nás dosud. Hlavními představiteli daného období byli C. Teddlie a A. Tashakkori. Do roku 1990 došlo k rozdělení kvantitativních a kvalitativních výzkumníků. Kvalitativní a kvantitativní výzkum byly chápány jako odlišná „paradigmata“. Situace do současnosti je charakteristická extrémní specializací kvantitativního a kvalitativního výzkumu a rozdělením odborníků na empiriky a teoretiky, přičemž chybí určitý střed. Relevantní se stala teze kompatibility kvantitativního a kvalitativního výzkumu za předpokladu pragmatismu.

Téma smíšeného výzkumu není tedy zcela novým tématem, i když v současném pojetí je něčím novým (srov. Creswell \& Plano Clark, 2007, s. 1). Moderní původ metodologické kombinace je spojován s Campbellem (Campbell \& Fiske, 1959).

\section{Závažnost tématu smíšeného výzkumu}

Téma je závažné vzhledem k nárůstu prací se smíšeným výzkumem. Od konce 20. století můžeme sledovat výraznou aplikaci smíšeného výzkumu i v České Republice, i když smíšený výzkum v disertačních a dalších pracích není často adekvátně terminologicky označovaný, zejména druhy smíšeného výzkumu.

V současnosti představuje smíšený výzkum samostatný směr, př́íp. hnutí (srov. Bergman, 2008). Smíšený výzkum přirozeně odpovídá výzkumným otázkám často kladeným v pedagogických disciplínách, zejména evaluačnímu výzkumu, který se ve formě smíšeného designu začal používat jako první.

Rozširrenení smíšeného výzkumu v posledních desetiletích lze konstatovat na základě:

- nárůstu publikací o smíšeném výzkumu (např. nakladatelství Sage),

- nárůstu jeho aplikací ve výzkumu, zvýšení počtu projektů,

- zahrnutí problematiky do učebnic a skript,

- založení časopisu Journal of Mixed Methods Research (v roce 2007 v nakladatelství Sage, Thomson Reuters jej řadí na 5. místo z 83 hodnocených časopisů v sociálních vědách s IF 2,2),

- pořádání konferencí zaměřených na smíšený výzkum (např. ve Velké Británii, Německu, USA),

- organizování sympózií a sekcí konferencí zaměřených na smíšený výzkum (např. EARLI, ECER, SSWR), 
- pořádání metodologických workshopů zaměřených na design smíšeného výzkumu (např. Velká Británie - zejména slavná Essex Summer School in Data Colection and Analyses, Švýcarsko, Jihoafrická republika, Německo, Slovinsko),

- zařazení samostatných seminářů o smíšeném výzkumu do vysokoškolské výuky.

Z tohoto hlediska se jedná pro odbornou pedagogickou veřejnost zabývající se výzkumem o téma závažné, kterým je třeba se teoreticky a metodologicky zabývat.

\section{Současné pojetí smíšeného výzkumu}

Pojetí kombinování kvantitativního a kvalitativního výzkumu se měnilo ve vazbě na změny v pojetí triangulace $\mathrm{z}$ hlediska jejího epistemologického zdůvodnění. V současnosti je smíšený výzkum chápán jako design výzkumu, kde je alespoň jeden kvantitativni aspekt kombinovaný s alespon̆ jedním kvalitativním východiskem (přistupem), sběrem dat a/nebo analýzou dat. Základním předpokladem je, že kvalitativni a kvantitativní př́stup současně umožňuji lepši pochopení výzkumného problému než pouze jeden z nich (srov. Creswell \& Plano Clark, 2007). Z výše uvedeného vyplývá, že smíšený výzkum není vhodný pro jakýkoli výzkumný problém nebo otázku, naopak výzkumný problém musí odpovídat smíšenému designu. Z čehož taktéž vyplývá, že smíšený design výzkumu není lepší nebo horší než design výzkumu s jednou metodou, nebo design s více metodami jen kvalitativními nebo jen kvantitativními. Jakožto metodologie má smíšený výzkum své filozofické východisko převážně v pragmatismu (Složilová, 2011).

\section{Př́nos smíšeného designu výzkumu - hlouběji do rovin výzkumu}

Př́nosů a výhod smíšeného výzkum je vícero, stejně jako jeho nevýhod. Za jednu z východ precizujících naše uvažování o komponentách výzkumného procesu lze považovat to, že nás smíšený design nutí jasně rozlišovat jednotlivé roviny výzkumu:

- teoretické př́stupy a východiska, teorie,

- sběr dat - metody a techniky,

- analýzu dat - metody a techniky.

$\mathrm{K}$ jasnému rozlišování úrovní nás vede především tzv. mixed model design (obr. 1) - smíšený design výzkumu s kombinací kvalitativních a kvantitativních prvků [teoreticky] na všech úrovních současně (formulace výzkumné otázky, techniky sběru dat, techniky analýzy dat, interpretace výsledků) nebo napříč těmito rovinami, např̀. kvalitativní výzkumná otázka a kvantitativní data (Tashakkori \& Teddlie, 2003). Tento typ designu představuje největší míru kombinování kvalitativních a kvantitativních komponent designu výzkumu. Koncept pochází od Creswella (1995), který ho nazýval původně mixed methodology design. 


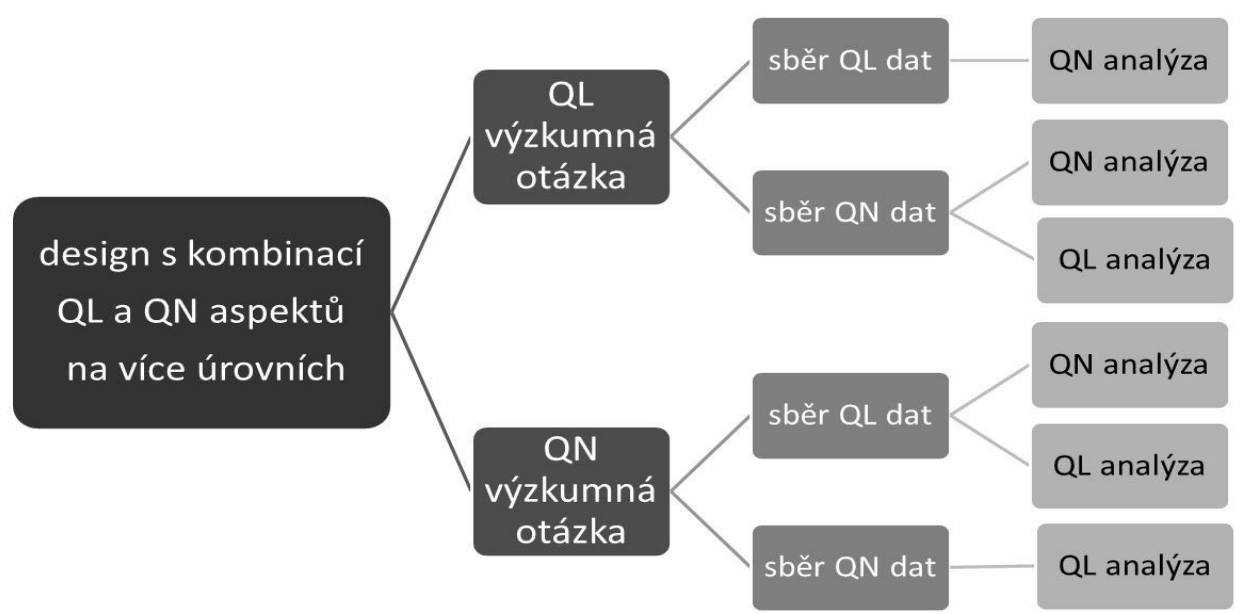

Obrázek 1. Mixed model design (podle Creswell, 1995)

\section{Modernost smíšeného designu výzkumu}

Dalším z přínosů smíšeného výzkumu je, že přirozeně vede $\mathrm{k}$ aplikaci „nejnovějších“ postupů vhodných právě pro pedagogické disciplíny, jimž je např́íklad víceúrovňová analýza dat, sekundární analýza dat nebo kontextuální model výzkumného designu.

- Tzv. víceúrovňová analýza dat, jakožto statistická technika pracuje s daty na více úrovních (např. na úrovni žáka, učební skupiny, třídy, ročníku, stupně školy, školy, typu školy, regionů a států). U podobné struktury dat lze na různých úrovních navazovat např. dalšími vhodnými kvalitativními technikami.

- Pro sekundární analýzu dat lze využívat zejména reprezentativní mezinárodně srovnávací výzkumy výsledků vzdělávání a navazovat na ně např. kvalitativními výzkumnými otázkami.

- Ve smíšeném výzkumu chronologický model výzkumu separovaný do let (obr. 2) naráží na mnoho svých limitů a přirozeně dochází $\mathrm{k}$ upřednostňování kontextuálního (konzistentního, vzájemně podmíněného) modelu (obr. 3). V něm je kladen důraz na to, jak změna jedné $z$ částí výzkumného designu $\mathrm{i} v$ průběhu realizace výzkumu ovlivňuje další prvky. Př́ípadně jak východisko našeho designu výzkumu (výzkumná otázka, data pro sekundární analýzu, aplikovaná analýza) determinuje všechny další prvky.

\begin{tabular}{|l|l|l|l|}
\hline 1. rok & 2. rok $\square$ & 3. rok $\square$ & 4. rok \\
\hline $\begin{array}{l}\text { rešerše literatury } \\
\text { výzk. otázka }\end{array}$ & data & analýzy & výsledky \\
\hline
\end{tabular}

Obrázek 2. Chronologické schéma výzkumného designu 


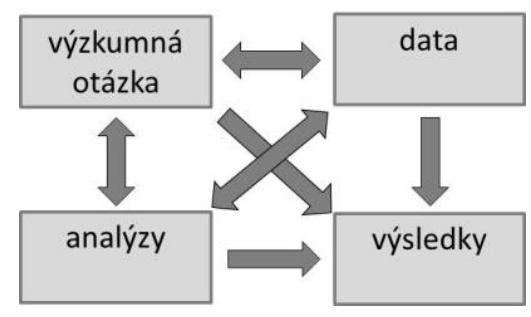

Obrázek 3. Kontextuální (podmíněný) model výzkumného designu

\section{Rozvoj české terminologie}

Jedním z úkolů pedagogiky a vůbec sociálních věd u nás je rozvíjet teorii smíšeného výzkumu a etablovat jeho terminologii. Mnoho termínů běžně používaných (a více či méně jasně definovaných) v zahraniční nenachází zatím své české ekvivalenty. Jedná se jak o termíny obecné (tab. 1), tak i specifická označení, především pro druhy smíšeného výzkumu.

Tabulka 1

Anglická a česká terminologie smišeného výzkumu

\begin{tabular}{|l|l|}
\hline Anglická terminologie & Možná česká označení \\
\hline mixed method design (MMD) & smíšený design výzkumu \\
\hline mixed methods (Creswell) & smíšené metody \\
\hline mixing methods (Brannen) & kombinování metod \\
\hline mixed methodologies (Tashakorri, Teddlie) & smíšené metodologie \\
\hline mixed research & smíšený výzkum \\
\hline mixed model design & $\begin{array}{l}\text { smíšený design výzkumu s kvantitativními a kvalitativními } \\
\text { prvky na více úrovních (víceúrovňové použití přstupú); } \\
\text { výzkum na základě smíšeného modelu (Hendl, 2008) }\end{array}$ \\
\hline mono-method design & design s jednou metodou \\
\hline multi-methods design & design s více metodami \\
\hline
\end{tabular}

\section{Závěr}

Zásadním přínosem současné teorie smíšeného výzkumu je aktualizování historicky podmíněného, překonaného pojetí a odlišování kvantitativního a kvalitativního výzkumu, a to jak v rovině př́istupů, metod sběru dat, tak nezřídka i na úrovni analýzy dat. Max M. Bergman (2008), John W. Creswell a Vicki L. Plano Clarková (2007) poukazují na mylnou záměnu kvalitativní metodologie s konstruktivismem a kvantitativního výzkumu s (post)pozitivismem. Přičemž i u této záměny se jedná o ideálně-typické připisování charakteristik daným metodologiím. V realitě minimum výzkumníků splňuje všechna ideálnětypická kritéria určité metodologie. Např́klad jen málo kvantitativních výzkumníků zastává pozitivistické, prŕípadně post-pozitivistické pozice a mnoho z nich se hlásí k umírněné variantě konstruktivismu.

Smíšený výzkum není ve své podstatě úplně novým tématem, nicméně v současném pojetí je novým konceptem (srov. Creswell \& Plano Clark, 2007, s. 1) a závažným tématem (srov. Bergman, 2008). Nová je myšlenka kombinování dat a také explicitní kombinování 
kvalitativních a kvantitativních dat ve specifickém metodologickém prístupu, dále např́iklad záznamový systém jednotlivých druhư smišseného designu výzkumu, terminologie nebo změny v použivání různých designů.

\section{Literatura}

Bergman, M. M. (2009). Advances in mixed methods research. London: Sage.

Brannen, J. (Ed.). (2003). Mixing methods: Qualitative and quantitative research. Hants: Ashgate.

Campbell, D. T., \& Fiske, D. W. (1959). Convergent and discriminant validation by the mulitraitmultimethod matrix. Psychological bulletin, 56(2), 81-105.

Cresswell, J. W. (1995). Research design: Qualitative and quantitative approaches. Thousand Oaks, CA: Sage.

Creswel, J. W., \& Plano Clark, V. L. (2007). Designing and conducting mixed methods research. London: Sage.

Denzin, N. K. (1978). The research act: An introduction to sociological methods. New York: McGraw-Hill.

Hendl, J. (2008). Kvalitativní výzkum. Praha: Portál.

Prenzel, M. (2011). More evidence is needed: What works and what does not work in education. In Conference EARLI: Invited EARLI symposium: The question of research methodology: Where next for EARLI? Exeter: University of Exeter.

Shavelson, R. J., \& Towne, L. (Eds.). (2002). Scientific research in education. Washington, DC: National Research Council, National Academy Press.

Složilová, E. (2011). Dobrý sluha nebo špatný pán? Pragmatismus jako filozofický základ smíšeného výzkumného designu. Pedagogická orientace, 21(1), 51-69.

Tashakkori, A., \& Teddlie, C. (Eds.). (2003). Handbook of mixed methods in social and behavioural research. London: Sage.

\section{Kontakt}

Doc. Mgr. et Mgr. Kateřina Vlčková, Ph.D.

Masarykova univerzita

Pedagogická fakulta, Institut výzkumu školního vzdělávání

Poříćí 31, 60300 Brno

e-mail:vlckova@ped.muni.cz

\section{Bibliografické údaje}

Vlčková, K. (2011). Smíšený výzkum: Jedná se o nové a závažné téma? In T. Janík, P. Knecht, \& S. Šebestová (Eds.), Smišsený design v pedagogickém výzkumu: Sborník přispěvki z 19. výroční konference České asociace pedagogického výzkumu (s. 1-6). Brno: Masarykova univerzita.

Dostupné z: http://www.ped.muni.cz/capv2011/sbornikprispevku/vlckova.pdf

doi: 10.5817/PdF.P210-CAPV-2012-84 